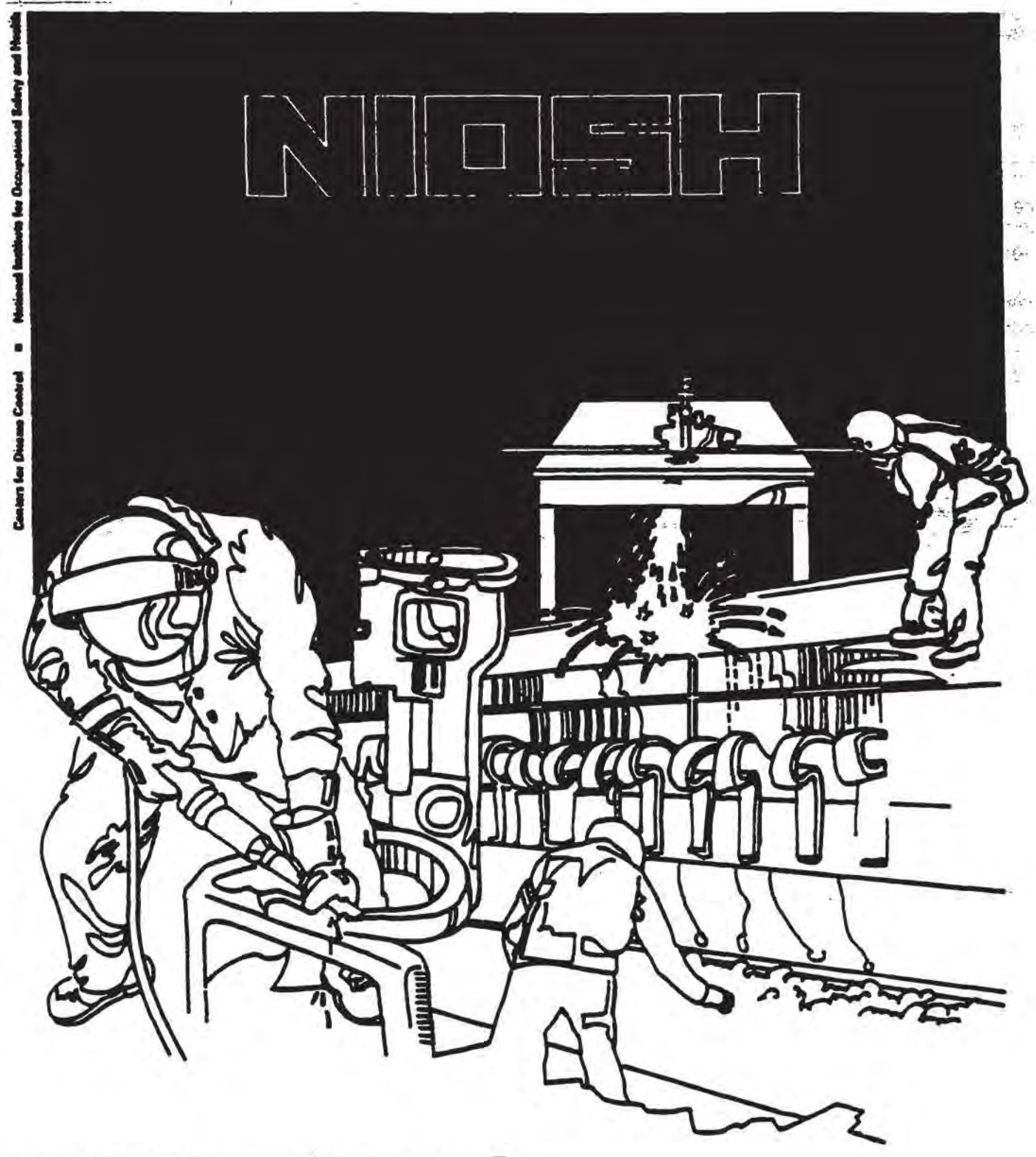

Health Hazard

Evaluation

Report
HETA 83-369-1672 LOCKHEED-GEORGIA COMPANY MARIETTA, GEORGIA 
The Hazard Evaluations and Technical Assistance Branch of NIOSH conducts fteld investigations of possible heelth hazards in the workplace. These investigations are conducted under the authority of Section $20(a)(E)$ of the Occupational Safety and Health. Act of 197C, 2S- U.S.C. 66S(a) (6) which authorizes the Secretary of Health and Human Services, following a written request from any employer or anthorized representative of employees, to determine whe ther any substance normaliy found in the place of employment fias potentially toxice effects in sich concentrations as used or found.

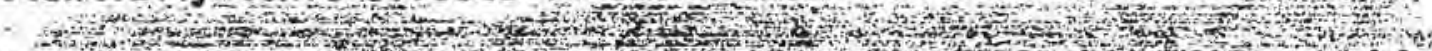
The Hazard Evaluations and Technical Assistance Branch also provides, upon request, medfcal, nursing, and industrial hygfene technical and consul tative assistance' (TA) to Federal, state, and Yocal agencies, labor; Industry and other groups or individuals to control occupational heal th hazards and to prevent related trauma and disease.

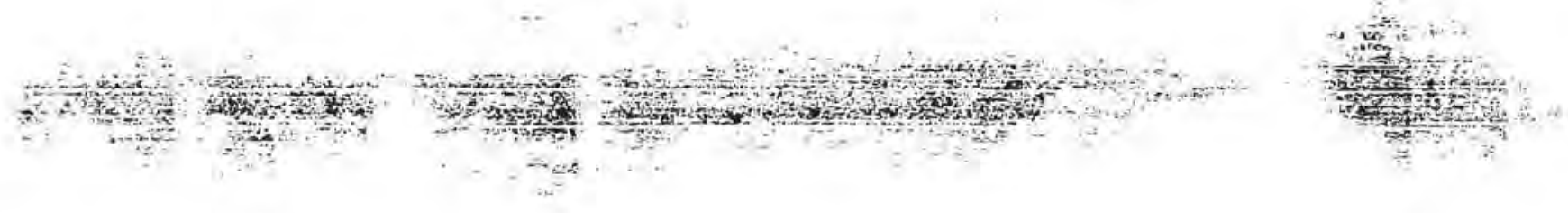

Mention of company names or products does not constitute endorsement by the Nationar Institute for Occupational Safety and Health. 
HETA $83-369-1672$

FEBRUARY 1986

LOCKHEED-GEORGIA COMPANY

MARIETTA, GEORGIA
NIOSH INVESTIGATORS:

Stan Salisbury, C.I.H. Rob McConne17, M.D.

Kent Anger, PhD.

\section{SUMMARY}

In July, 1983, the National Institute for Occupational Safety and Health (NIOSH) received a request to evaluate a potential health hazard in Building 84, at the Lockheed-Georgia Plant, Marietta, Georgia, where parts removed from C5A aircraft wings were being spray-cleaned with solvents $(1,1,1$-trichloroethane or a solvent blend known as Turco $\left.{ }^{\text {th }} \mathrm{T}-1000\right)$.

NIOSH investigators first visited Building 84 on August 18, 1983. Although solvent spray cleaning was done inside an exhaust ventilated booth, employees working near the hooth and inspectors checking previously cleaned wing parts, complained that vapoirs from the booth, and residual solvents evaporating from the parts were causing headaches, coughing, burning eyes, sinus problems, and nausea. Analysis of bulk air samples taken in the breathing zone of the potentially exposed workers identified 1,1,1-trichloroethane, methylene cnloride, tetrachloroe thy iene, diacetone alcohol, n-butanol, trimethyl benzene, 1,4-dioxane, acetone, indane, and xylene in the vapors released near the spray booth. Recommendations for further reducing solvent vapor exposures were made by NIOSH in an interim report issied September 16, 1983. To the extent feasible, these recommendations were implemented by Lockheed prior to a NIOSH follow-up survey at the plant on February $6-7,1984$.

During the follow-up epidemiologic study, quantitative personal air sampling detected low-level exposures to solvent vapors, but concentrations were we11 below NIOSH evaluation criteria. The hignest exposures found were: $23 \mathrm{ppm} \mathrm{1,1,1-trichloroethane}$ (350 ppm limit), $5.8 \mathrm{ppm}$ methylene chloride (75 ppm 1 imit), $2.8 \mathrm{ppm}$ tetrachloroethylene (50 ppm 1 imit*), $1.2 \mathrm{ppm}$ aromatic hydrocarvons (as trimethyl benzene, $25 \mathrm{ppm}$ Timit), $0.2 \mathrm{ppm}$ ciacetone alcohol ( $50 \mathrm{ppm}$ limit), $0.5 \mathrm{ppm}$-butyl alcohol (50 ppm limit), and $0.2 \mathrm{ppm}$ xylene (100 ppm limit). The exposures for the solvent sprayer during the follow-up survey were lower than expected, but only small wing parts were being sprayed.

Measurements of blood carboxyhemoglobin, total urinary trichlorocompounas and m-methyl hippuric acid were within or below normal levels in both exposed and unexposed workers, and no significant change across the work shift was noted in exposed workers.

* Note: NIOSH considers tetrachioroethylene (perchloroethylene) to be a suspect carcinogen and recommends exposures be reduced to the lowest technicaliy feasible limit. The current exposure limit (ACGIH TLV) recommended for protection against effects on the central nervous system is $50 \mathrm{ppm}$. The OSHA Permissinte ExDosure Limit is $100 \mathrm{ppm}$. 
To evaluate neurotsixic effects resuiting from potential exposures to volatile organic compounds, a battery of neurobehavioral tests was administered to the seven exposed Horkers and to a comparison group of thirteen unexposed workers in another part of the $p$ lant.

Exposed workers performed worse than unexposed workers on the Bourdon-Wiersma test $(p=0.001)$, a test of attention and alertness. Exposed workers al so scored worse $(p=0.02)$ than the unexposed workers on a Multi-Attention test. Because multiple comparisons ivere made, this latter result is of marginal statistical significance. Both these tesis measured related functions (attention and alertness), suggesting there are real differences between the exposed and unexposed groups. Although these differences couid reflect the chronic effects from previous solvent exposures in the exposed group's current or former jobs at the plant, an inadvertent study bias could also account for these aifferences.

There were no differences between exposed and unexposed workers in performance on tests of simple reaction time as determined from: the Santa Ana Dexterity Test or the Hechsler Memory Scale. Comparisons between morning and afternoon performances of exposed and unexposed workers were unremarkable. This was not surprising because on ty low solvent vapor exposures were measured at the time of the testing. There vere no statistically significant differences between the two groups of workers in the prevalence of neurologic or irritative symptoms.

No solvent exposures above NIOSH-recommended limits were detected ciuring our visit. Differences in reurovehavioral performance between exposed and unexposed workers could not conclusively he actributen to solvent exposures received prior to the NIOSH site visit. Recommendations were made to maintain solvent exposures at low levels.

KEYWORDS: SIC 3721 (Aircraft Manufacturing), methviene chioricle, 1,1,1-trichloroethane, tetrachlornethylene, solvents, central nervous system toxicity, neurobehavioral effects. 
Hazard Evaluation and Technical Assistance Report No. 83-369

II. INTRODUCTION

On July 21,1983 , NIOSH received a request for a health hazard evaluation at the Lockheed-Georgia Plant in Marietta, Georgia. An authorized representative with the Aeronautical Machinists and Aerospace Workers, Lodge 709 , asked NIOSH to investigate health hazards in Building 84 , where reusable parts removed from C5A aircraft wings were being spray-cleaned with chlorinated hydrocarbon solvents inside an exhaust ventilated spray booth.

On August 18, 1983 a site visit was made to the plant to discuss the request and ensuing evaluation with company and union representatives, and to conduct a walk-through survey. NIOSH representatives observed the wing parts spray-cleaning procedures in Building 84, interviewed employees working in Building 84, measured the exhaust face velocity of the spray booth, and collected bulk air samples to determine the composition of the airborne vapors detectable in Building 84. An initial response letter with preliminary results from this survey was sent to Lockheed and Union representatives on September 16, 1983.

On February 6-8, 1984, NIOSH conducted a follow-up study to: (1) compare symptoms of neurologic and irritant effects of solvent exposure among solvent-exposed and comparable unexposed workers, (2) to objectively measure neurologic performance of the two groups, and (3) to collect air samples to measure individual personal exposures to solvent vapors from workers in each group. The air sampling results from this survey were forwarded to Lockheed and to the employee representatives on March 21, 1984.

III. BACKGROUND

The Lockheed-Georgia Company, in Marietta, Georgia manufactures military cargo aircraft for the U.S. Armed Forces as well as some foreign countries. The C130, C141, and C5A Aircraft were built at this plant. At the time of the NIOSH survey, C5A aircraft from the U.S. Air Force were being returned for new wings because of structural defects in the existing wings. All reusable components from the old wings were removed from the aircraft and brought to Building 84 (a 36,000 sq.ft. aircraft hanger).

To remove dirt and grease, the parts were loaded onto a cart and rolled into a large ( 16 feet high by 12 feet wide) exhaust

ventilated spray booth where they were sprayed down with solvent. The spray booth was large enough to accommodate the C5A's wing flaps and ailerons. Only one worker did the spraying. When spraying, he wore a two-piece neoprene rubber rain suit, rubber gloves, boots, face shield, rubber hood, and a half-mask respirator with organic vapor cartridges. Although the booth was generally effective in capturing the solvent vapors released, personal protection was required because the worker spraying occasionally 
Hazard Evaluation and Technical Assistance Report No. 83-369.

was required to stand between the part being sprayed and the exhaust slots at the rear of the booth. The solvent was pumped directly from a 55 gallon drum to a hand-held high pressure spray wand. Although most of the solvent spray evaporated, a sump pit under the booth collected any residual waste solvent or grease removed from the wing parts. After cleaning, the parts were rolled out of the booth for inspection. Parts found defective were repaired, pending Air Force approval.

About 34 drums of solvents were used each month. One of two degreasing solvents was used, Vulcan ${ }^{\circledR}$ Solvent 111 or Turco ${ }^{\circledR}$. T-1000. Turco ${ }^{\circledR} T-1000$ was used on parts heavily coated with grease; otherwise, workers used Vulcan ${ }^{\circledR}$ Solvent 111 . According to the suppliers, the solvents had the following compositions:

Solvent $11198 \%$ 1,1,1-trichloroethane

$2 \%$ 1,4-dioxane (a stabilizer)

Turco T-1000 35\% perchloroethylene

$30 \%$ methylene chloride

$25 \%$ aromatic petroleum solvents

$5 \%$ diacetone alcohol

$5 \%$ n-butyl alcohol

Personal breathing zone air samples from the solvent sprayer, and area air samples from the face of the spray booth entrance were collected on activated charcoal tubes for later qualitative analysis by gas chromatography and mass spectrophotometry (GC/MS). Based on these analyses, 1,1,1-trichloroethane, methylene chloride, perchloroethylene, aromatic solvents (as trimethyl benzene), diacetone alcohol, n-butyl alcohol, and xylene were the organic vapors selected for further exposure monitoring.

Employees standing near the spray booth inspecting the cleaned aircraft parts complained that vapors from the booth, and residual solvent evaporating from the parts removed from the booth, were causing headaches, coughing, burning eyes, sinus problems, and nausea. Since these irritant and central nervous system effects were consistent with the known effects of exposure to solvent vapors, and because few controlled field studies of irritant, neurobehavioral effects of low-dose exposure to these common solvent mixtures had been done previously, NIOSH investigators decided to conduct a follow-up study. Our objective was to compare symptoms of neurologic and irritant effects of solvent exposure among solvent-exposed workers, with a comparison group of unexposed workers. This was accomplished by objectively measuring neurologic performance of the two groups and by quantitating personal exposures to the volatile organic compounds previously identified in the bulk air samples collected during the initial NIOSH survey. 
llazarc Evaluation and Tecnnical Assistance Report No. 83-369

IV. EVALUATIUN DESIGN AND METHODS

A. Environmenta 1

In Building 84 on the morning of February 7 th, 1984, five personal air samples and ona area sample were collected when wing parts were spray cleaned with Turcom $T-1000$ solvent. The samples were collected on activated charcoal tubes using pre-calibrated battery powered vacuum pumps. The methoos used for sampling and analysis of the volatile organics contained in Turco" T-1000 are summarized below.

\begin{tabular}{|c|c|c|c|c|}
\hline ANALYTES & $\begin{array}{l}\text { AIAPLE PUMP } \\
\text { FLOW RATE } \\
\end{array}$ & ANALYTICAL METHOD & & REFERENCE \\
\hline methylene chloride & $0.02 \mathrm{Lpm}$ & Gas Chromatoaraphy & NIOSH & Method S-3291 \\
\hline $\begin{array}{l}\text { tetrachloroethylene } \\
\text { Aromatic solvents } \\
\text { (as trimethyl benzene) } \\
\text { xylene }\end{array}$ & $\begin{array}{l}0.1 \mathrm{Lpm} \\
\text { ) }\end{array}$ & Gas Chromatography & NIOSH & $\begin{array}{c}\text { Method } 127^{2} \\
\text { " }\end{array}$ \\
\hline $\begin{array}{l}\text { n-hutyl a lcohol } \\
\text { diacetone alcohol }\end{array}$ & $0 . \frac{1}{\mathrm{u}} \mathrm{Lpm}$ & Gas Chromatography & NIOSH & Method $S-6 f^{3}$ \\
\hline
\end{tabular}

During the afternoon of February $7 \mathrm{th}$, an additional seven personal air samples and one area air sample were collected when wing parts were being cleaned with Vulcan ${ }^{m}$ Solvent 111 . The samples vere collected on activated charcoal tubes using pre-calibrated tattery powered vacuum pumps set for a sample collection flow rate of 0.1 Lpm. The samples were analyzed by gas chromatography using NIOSH Method $\mathrm{S}-328.4$

To verify that che unexposed comparison group of workers used as controls were not exposed to solvents, personal air samples were collected from each plant location where these workers were assigned. The samples were collected and analyzed for the volatile organics sampled in Building 84. These locations were also monitored qualitatively by collecting bulk air samples on charcodl tubes for later analysis hy GC/MS to identify possible exposures to other volatile organic compounds.

\section{B. Meaica1}

The stuay population consisted of seven solvent-exposed workers in Building 84, and 13 other workers selected from production areas in other parts of the plant kaving no solvent exposure. Each "nonexposed" worker chosen had the same sex, race, and age (within five years) as a particular exposed worker. This resulted in 1-3 "nonexposed worker(s)" for each exposed worker. Of the siaht solvent-exposea workers, seven agreed to participate in the 
study. Workers for the control group were first selected by factors of sex, age, and race from personnel lists of shipping and receiving workers. However, after the NIOSH representatives met with these workers to explain the study, only three of the 14 workers selected agreed to participate. To complete the study, eight male comparison workers were selected from the tool design area, where all but one eligible control agreed to participate. Two "nonexposed" female steno clerks also agreed to participate. Al together, NIOSH found thirteen control workers to participate in the study. In each of the control work areas there was little possibility for solvent exposure.

The solvent-exposed workers included the solvent sprayer who worked inside the booth, various inspectors of cleaned parts, and two structural repairmen who worked in one corner of Building 84 . The structural repairmen worked in an area furthest from the spray booth but they also used a small amount of methyl ethyl ketone in their jobs.

Demographic characteristics of exposed and "not-exposed" workers are described in Table 1. There were fewer black workers in the "not-exposed" group (23\%) than in the exposed group (43\%). The exposed workers were 3.6 years older than the "not-exposed".

All participating workers were administered a questionnaire. Prevalence of mucous membrane and respiratory irritation symptoms was determined. A questionnaire, widely used clinically and epidemiologically in evaluating solvent-exposed workers in Sweden ${ }^{5}$, was used to assess neurobehavioral symptom prevalence.

Exposures were assessed by environmental monitoring (as described above) and by biological monitoring of total urinary trichlorocompounds and blood carboxyhemoglobin. Upon arriving at work and again in the afternoon after completing the neurobehavioral testing session, each exposed worker submitted a blood and urine sample and each "not-exposed" worker submitted a urine sample. The following biological measurements were made:

SOLVENT

Perchloroethylene Methyl chloroform

Xylenes

Methylene chloride
BIOLOGICAL METABOLITE

Total urinary trichloro- compounds analyzed colorimetrically by the method of Tanaka and Ikeda) 6

Urinary m-methyl hippuric acid (by high pressure liquid chromatography using a modification of NIOSH Nethod 8301) 7

Carboxyhemoglobin (exposed workers only --determined on Instrumentation Laboratories co-oximeter) 
Hazard Evaluation and Technical Assistance Report No. 83-369

Perchloroethylene is metabolized to trichloroacetic acid, which is excreted in the urine. A one week exposure to perchloroethylene at the permissible exposure limit of $100 \mathrm{ppm}$ is reported to produce $10 \mathrm{mg}$ of trichloroacetic acid/gram creatinine in the urine. 1,1,1-Trichloroethane is metabolized to (and renally excreted as) both trichloroacetic acid and as trichloroethanol. In this study NIOSH measured total trichloro- compounds to reflect the combined exposure to 1,1,1-trichloroethane and perchloroethylene. Exposures to 1,1,1-trichloroethane at the recommended NIOSH 1 imit of $350 \mathrm{ppm}$ would likely produce less than $50 \mathrm{mg} / \mathrm{gm}$ creatinine total trichloro- compounds after one shift's exposure.8 Xylene is metabolized to methyl hippuric acid. Carboxyhemoglobin is a metabolite of methylene chloride. The normal carboxyhemoglobin range for non-smokers is $0.5-2.0 \%$. For smokers, the normal range is less than $12.0 \%$.

\section{Neurobehavioral Tests}

To assess neurologic performance objectively, all workers were administered a battery of neurobehavioral tests:

Simple Reaction Time Test: This is a test of speed of response using two buttons. The subjects' task was to press button 1 until button 2 1ighted, then release button 1 and press button 2 as rapidly as possible. Data collected were measures of release time (from button 1) and response time to push button 2 (in milliseconds). There were 50 trials, but the first 17 trials were discarded to account for the rapid improvements in speed that normally occur from practice. The first 17 trials included all release times slower than 750 milliseconds (msec) and all response times slower than $500 \mathrm{msec}$, our recommended maxima for these types of data.

Santa Ana Test: This test of eye-hand coordination utilizes four rows of pegs in square holes. The subject's task was to rotate (180 degrees) as many pegs as possible in the 30 seconds allowed. The total number of pegs rotated was the measured score.

Wechsler Memory Scale Test: In this test of short-term memory, two stories were read (using a tape recording) to the subjects. Participants were asked to recall all the facts they could at the end of each story. The data were the mean number of discrete memories from the two stories.

Multi-Attention Task: This task of attention and alertness presented three columns of symbols on a video display screen. The subject's task was to identify symbols that differed (the distractors) from those that were expected. In the test, three columns were displayed with the headings 7, 8, and 9 . Under columns 7 and $9,3 \times 4 \mathrm{~mm}$ asterisks appeared at vertical intervals of $5 \mathrm{~mm}$. Occasionally, pluses of the same size appeared, which 
were the distractors. The middle column, labelled 8 , contained $3 \times 4 \mathrm{~mm}$ numbers, also $5 \mathrm{~mm}$ apart, and the distractors here were $3 \times 4 \mathrm{~mm}$ letters. At the beginning of the test, a single symbol appeared in each column, so that a row of 3 symbols (e.g., asterisk, number, asterisk) was presented, followed shortiy thereafter by the next row, and so forth. The subject pushed one of three keyboard buttons labelled 7, 8, or 9 to indicate where a distractor appeared on the screen. There were either none, one, or two distractors per row, requiring no response, a one-button press, or a two-button press for any given row. Generally, there were no distractors in a given row. The screen blanked after ten rows appeared and a new "screen" of ten rows were presented in the same fashion. Ten separate or unique "screens" were presented and each screen was repeated two times for a total of 30 screens. The speed at which each succeeding row appeared began at $1400 \mathrm{msec}$ between row presentations and progressed to 1200 and then $800 \mathrm{msec}$ (10 1/2 screens or 10 screens plus 5 rows of the 11 th screen at $1400 \mathrm{msec}, 10$ screens at $1200 \mathrm{msec}$, and $91 / 2$ screens at $800 \mathrm{msec}$ ). Data collected were the number of differing symbols or distractors correctly detected by the subject at the three different speeds of presentation.

Bourdon-Wiersma Test: Sustained attention, or vigilance, and rapid hand movements were required for this test. The participant was given a sheet of paper containing 400 sets or groupings of 3,4 , or 5 dots and told to cross out as many sets of 4 dots as possible in 8 minutes. Each set of dots occupied an area of roughly $4 \mathrm{~mm}$, and the sheet was organized in rows of 50 sets with $2 \mathrm{~mm}$ between sets and $4 \mathrm{~mm}$ between rows. The number of sets of 4 dots crossed out was recorded for each subject.

A11 tests were administered to each subject in the morning and again in the afternoon of the same day. Only two subjects could be tested at any one time; therefore, workers were tested at half hour intervals throughout the morning and again in the same order in the afternoon. About five hours separated the tests for each worker.

Differences between prevalence of various symptoms among exposed and matched "non-exposed" workers were analyzed using conditional logistic regression for matched case-control studies (Cox proportional hazard model for one case per matched set).9

Neuroperformance data from 20 subjects were collected. The three females ( 1 exposed and 2 unexposed) were not analyzed because of the small number, and the expectation that data from males and females could not be combined in a single analysis. Of the remaining subjects, three solvent-exposed workers were white and three were black. Seven unexposed subjects were white and four were black. The mean age was 48.8 for the exposed subjects and 44.9 years for the unexposed. The M-RANK nonparametric procedure 
Hazard Evaluation and Technical Assistance Report No. 83-369

was used to compare performance between exposed and control participants. 9 To be as sensitive as possible to potential differences in this exploratory analysis, each comparison was undertaken as an independent analysis. NIOSH evaluated acute effects among solvent-exposed workers by comparing morning with afternoon performance on the neurobehavioral test battery. In addition, afternoon performance in exposed vs. control workers was compared to assess possible chronic effects of solvent exposure.

V. EVALUATION CRITERIA

A. Environmental Criteria

As a guide to the evaluation of the hazards posed by workplace exposures, NIOSH field staff use environmental evaluation criteria for assessment of many chemical and physical agents. These criteria are intended to suggest levels of exposure to which most workers may be exposed up to 10 hours per day, 40 hours per week for a working lifetime without experiencing adverse health effects. However, not al1 workers will be protected from adverse health effects if their exposures are maintained below these levels. A small percentage may experience adverse health effects because of individual susceptibility, a pre-existing medical condition, or a hypersensitivity (allergy).

In addition, some hazardous substances may act in combination with other workplace exposures, the general environment, or with medications or personal habits of the worker to produce health effects even if the occupational exposures are controlled at the level set by the evaluation criterion. These combined effects are often not considered in the evaluation criteria. Also, some substances are absorbed by direct contact with the skin and mucous membranes potentially increasing the total exposure. Lastly, evaluation criteria may change over the years as new information on the toxic effects of an agent becomes available.

The primary sources of environmental evaluation criteria for the workplace are: (1) NIOSH criteria documents and recommendations, (2) the American Conference of Governmental Industrial Hygienists' (ACGIH) Threshold Limit Values (TLVs), 10 and (3) the U.S. Department of Labor (OSHA) occupational safety and health standards. 11 often, the NIOSH recommendations and ACGIH TLVs are lower than the corresponding OSHA standards. Both NIOSH recommendations and ACGIH TLVs usually are based on more recent information than are the OSHA standards. The OSHA standards also may be required to take into account the feasibility of controlling exposures in various industries where the agents are used; the NIOSH-recommended standards, by contrast, are based solely on concerns relating to the prevention of occupational disease. When considering the exposure levels and the recommendations for reducing these levels found in this report, it should be noted that employers are legally required to meet only those levels specified by an OSHA standard. 
The various criteria proposed by OSHA, ACGIH, and NIOSH for the airborne concentrations of the volatile organic compounds measured in this evaluation are listed in Table 2. A time-weighted average (TWA) exposure refers to the average airborne concentration of a substance during a normal 8- to 10-hour workday. Some substances have recommended short-term exposure limits (STEL) or ceiling values which are intended to supplement the TWA where there are recognized toxic effects from high short-term exposures.

For the purposes of this evaluation, NIOSH has selected the most stringent exposure limits as our evaluation criteria. The major health effects anticipated for workers exposed above these evaluation criteria are summarized in Table 2. A further discussion on the toxicity of several of the volatile organic compounds evaluated in this study is presented below.

\section{Acute Affects from Solvent Vapor Exposures}

Perchloroethylene is an eye irritant at 50-100 ppm.12 $1,1,1$-Trichloroethane is reported to have an objectionable odor at 350 ppm. 12 Transient eye irritation has been reported at 500 ppm. 13 Methylene chloride is a potent skin and eye irritant. 12 Trimethyl benzene, xylene, n-butyl alcohol (n-butanol), and diacetone alcohol are also respiratory or eye irritants at concentrations near the TLV.12

\section{Methylene Chloride}

Methylene chloride vapor is rapidly adsorbed via the lungs. At exposures normally encountered in industrial settings most of the methylene chloride is metabolized by the body to form carbon monoxide and probably carbon dioxide. Inhalation of methylene chloride is known to el evate carboxyhemoglobin levels.12 This may pose a significant risk to patients with pre-existing cardiovascular disease. NIOSH recommends a time-weighted average (TWA) exposure limit to methylene chloride of $75 \mathrm{ppm}$ to maintain carboxyhemoglobin 1 evels below $5 \%$ in non-smokers. 14 Methylene chloride may also impair central nervous system function at higher exposure concentrations. Methylene chloride is a mutagen, and there is some evidence that it may be an animal carcinogen. There is equivocal evidence of teratogenic effects as we11.15

Results recently published from a two-year inhalation study where mice and rats were exposed up to 4 times a day to methylene chloride at concentrations 2-4 times above the OSHA PEL have demonstrated that methylene chloride can produce lung and liver cancers in mice and benign tumors in the mammary glands of rats. These effects were not observed at the lower concentrations.16 Methylene chloride therefore fits OSHA's definition as a potential carcinogen. A NIOSH "Current Intelligence Bulletin" (CIB) is now being prepared which will address these recent findings. 
Hazard Evaluation and Technical Assistance Report No. 83-369

\section{Tetrachloroethylene}

In addition to its more frequently noted effect on the nervous system, causing dizziness, headache, vertigo, or light narcosis, the International Agency for Research on Cancer (IARC) has concluded that tetrachloroethylene (perchloroethylene) should be regarded as a suspect. carcinogen based on tests with laboratory animals.17 The results from a 1985 National Toxicology Program study have demonstrated a carcinogenic potential from inhalation of perchloroethylene in both sexes of mice and in male rats 18

In light of these results, perchloroethylene may be reclassified from a possible to a probable human carcinogen.19 NIOSH

currently recommends this substance be handied in the workplace as a potential human carcinogen. 20

\section{1,1,1-Trichloroethane}

$1,1,1-$ Trichloroethane is irritating to the eyes on contact. Exposure to the vapor depresses the central nervous system. Symptoms include dizziness, incoordination, drowsiness, and increased reaction time. Unconsciousness and death can occur from exposure to excessive concentrations.21 A few scattered reports have indicated mild kidney and liver injury in humans from severe exposure; animal experiments have confirmed the potential for liver, but not for kidney injury. Skin irritation has occurred from experimental skin exposure to the liquid and from occupational use. 22 Because of its structural similarity to other chloroethanes which cause cancer in animals, 1,1,1-trichloroethane is being evaluated for carcinogenicity.

\section{1,4-Dioxane}

Present as a chemical stabilizer in Vulcan ${ }^{\circledR}$ Solvent T-111 (98\% 1,1,1-trichloroethane and $2 \%$ 1,4-dioxane), dioxane is a suspect carcinogen, and NIOSH recommends reducing exposures to carcinogens to the lowest technically feasible level. Exposures should not exceed $1 \mathrm{ppm}$ for a 30-minute exposure duration, the lowest level of detection by current sampling and analytical methods. 23

VI. RESULTS

\section{A. Environmental}

Solvent vapor exposures monitored in Building 84, during spraying of C-5A wing components, were below levels which would be expected to cause adverse health effects for Lockheed employees working near the spray booth. The results presented in the Tables 3 and 4 represent the average concentrations for the duration of the sampling period. The solvent sprayer's TWA exposures to airborne solvent vapors were below NIOSH recommended 1 imits but considerable time during his sampling period did not involve actual spraying. The sprayer would likely have higher short term 
exposures during spraying, especially when spraying the very large wing components such as wing flaps and aileron. The sprayer was therefore required to wear personal protective clothing and NIOSH approved respiratory protection when working in the spray booth.

As presented in Table 3, exposures to the components of Turco $\mathrm{T}-1000$ fell within the following ranges:

\begin{tabular}{|c|c|c|}
\hline TURCO T-1000 COMPOSITION & EXPOSURES DETECTED (ppm) & EXPOSURE LIMIT \\
\hline $\begin{array}{l}30 \% \text { methylene chloride } \\
35 \% \text { perchloroethylene } \\
25 \% \text { aromatic solvents } \\
5 \% \text { diacetone alcohol } \\
5 \% \text { n-butyl alcohol } \\
\text { (trace) xylene }\end{array}$ & $\begin{array}{r}\text { ND }-5.7 \\
0.2-2.8 \\
0.1-1.2 \\
\text { ND }-0.2 \\
\text { ND }-0.5 \\
\text { ND }-0.2\end{array}$ & $\begin{array}{lll} & 75 & \mathrm{ppm} \\
& 50 \mathrm{ppm}^{\star} \\
& 25 \mathrm{ppm}^{\star \star} \\
& 50 \mathrm{ppm} \\
\mathrm{C} \quad & 50 \mathrm{ppm} \\
& 100 \mathrm{ppm}\end{array}$ \\
\hline $\begin{array}{l}C=\text { ceiling limit } \\
\text { * Potential carcinogen - } \\
\text { technically feasible } 1 \\
\text { ** as trimethyl benzene }\end{array}$ & $\begin{array}{l}\text { exposures should be redu } \\
\text { imit (LTFL) }\end{array}$ & to the lowest \\
\hline
\end{tabular}

Table 4 shows the level of exposures during use of Vulcan ${ }^{\circledR}$ Solvent 111. This solvent contains 98\% 1,1,1-trichloroethane. TWA exposures in building 84 during the period of application ranged from 0.5 - $23 \mathrm{ppm}$. The NIOSH recommended exposure limit for $1,1,1$-trichloroethane is $350 \mathrm{ppm}$.

Except for the Tool Design area, only trace amounts of solvents (typical ambient air background levels) were detected on bulk air samples collected in "non-exposed" control areas. A small concentration of normal-hexane (about $0.1-0.2 \mathrm{ppm}$ ) was found in the tool design area, and one Tool Designer, selected as a control subject, was exposed to $0.7 \mathrm{ppm}$ xylene. Although these were insignificant concentrations when compared to the recommended occupational exposure 1 imits for $n$-hexane $(50 \mathrm{ppm})$ and xylene (100 ppm), the finding does imply that subjects selected as controls from the Tool Design area were not completely free of solvent vapor exposures in their work areas. The source of these exposures were not specifically identified but they may come from aerosol spray adhesives used to hold down mechanical drawings.

The results from the bulk air samples collected for identification of any volatile organic compounds present in Building 84 and in the work locations of the selected "non-exposed" comparison group are presented below. Only the volatile organic compounds estimated to have the highest airborne concentration are listed. In all areas sampled the airborne concentration of any volatile organic compound identified was less than $0.3 \mathrm{ppm}$. 
Hazard Evaluation and Technical Assistance Report No. 83-369

\begin{tabular}{|c|c|c|}
\hline AREA SAMPLED & VOLATILE ORGANICS IDENT IFIED & ESTIMATED CONCENTRATI \\
\hline Building 84 & $\begin{array}{l}1,1,1-\text { trichloroethane } \\
\text { perchloroethylene }\end{array}$ & $\begin{array}{l}0.03-0.07 \mathrm{ppm} \\
0.04-0.08 \mathrm{ppm}\end{array}$ \\
\hline Building 83 & $1,1,1$-trichloroethane & $0.03-0.07 \mathrm{ppm}$ \\
\hline Tool Design & $\begin{array}{l}\mathrm{C}_{6} \text { alkanes i.e.: } \\
\text { methylpentanes } \\
\text { hexane } \\
\text { methylcyclopentane } \\
\text { cyclohexane }\end{array}$ & $0.1-0.2 \mathrm{ppm}$ \\
\hline
\end{tabular}
Materials Receiving toluene $\quad<0.02 \mathrm{ppm}$
Traffic Office toluene $0.05 \mathrm{ppm}$
Paint Stores toluene $0.15-0.25 \mathrm{ppm}$
(rec. \& insp.)
B. Medical
Two of the seven workers exposed to solvents complained of previous episodes of headache, nausea, lightheadedness, and lethargy associated with heavy use of solvents in the spray booth. Symptoms subsided on weekends, and were worse when large parts requiring large volumes of solvent were being cleaned. None of the symptoms evaluated in the questionnaire survey were statistically significantly more prevalent in either the exposed or the unexposed group (See Table 5). However this is not surprising, considering the small sample size, where only a large proportional difference in symptom prevalence would be detected by a questionnaire survey.

Only norinal amounts of blood carboxyhemoglobin and urinary total trichloro- compounds were detected on the day of the sampling lexcept for one worker who had an elevated carboxyhemoglobin level that was unchanged over the work shift and probably caused by smoking). Among the exposed non-smoking workers who submitted blood samples, the average pre-shift carboxyhemoglobin was $1.6 \%$ ( range $1.3-2.0$ ), and mean post-shift carboxyhemoglobin was also $1.6 \%$ (range $1.2-2.1$ ). There was no increase between average morning and afternoon values in either the exposed or unexposed group for either of the two indices of absorption ( $p>.05$ by student's t-test). Pre-shift mean total urinary trichlorocompounds were $0.2 \mathrm{mg} / \mathrm{g}$ creatinine (range $0-0.8$ ) for exposed and $0.4 \mathrm{mg} / \mathrm{g}$ creatinine (range $0-2.6$ ) for unexposed. Post-shift exposed workers had average urinary trichloro- levels of $0.3 \mathrm{mg} / \mathrm{g}$ creatinine (range $0-1.2$ ). Neither differences across the shift nor differences between exposed and unexposed workers were significant ( $p>0.05$ by student's t-test). In all workers, urinary m-methyl hippuric acid was not detectable. 
Hazard Evaluation and Technical Assistance. Report No. 83-369

These results are consistent with the low levels of exposure measured in air samples. However, workers commented that solvent exposures were probably lower than normal at the time of our visit because only small parts were being sprayed. Also, outside temperatures were sub-freezing, and the solvents may have volatilized to a lesser extent than would occur in warmer weather.

\section{Neurobehavorial Test Results}

Based on the air and biological monitoring results presented above, it would be surprising to find acute differences (over the course of the work shift) in the neurobehavioral performance of exposed and unexposed workers. However, it is possible that over several months, under a more normal solvent spray cleaning schedule, worker exposures to higher concentrations of airborne solvents may have caused chronic impairment of neurobehavioral function, which would be reflected in differences in performance between exposed and unexposed workers (see Table 6).

\section{Simple Reaction Time}

Response times in milliseconds (msec) are presented in Table 6. The times from the onset of the light in the response button to release of the first button (release time), measured during near the start of the workshift, averaged $329 \mathrm{msec}$ for the unexposed controls and $338 \mathrm{msec}$ for the exposed workers. The times from release of the first button to press of the second response button (response time) averaged $185 \mathrm{msec}$ for the preshift unexposed control subjects and $212 \mathrm{msec}$ for the exposed group. Although the exposed were slower in most but not all cases, the differences did not approach statistical significance.

\section{Santa Ana Test}

The average number of pegs turned ranged from 17 to 19 for the two groups. Because of an error in the data storage program, data were not recorded in the morning for the exposed workers. The differences between unexposed and exposed workers in the afternoon were not significant, al though exposed workers turned more pegs than the unexposed workers.

\section{Wechsler Memory Scale}

Both exposed and unexposed workers respectively remembered an average of 1.5 and 1.6 more facts in the afternoon than in the morning. This was expected, as the subjects were read the same stories in the afternoon as in the morning. The unexposed subjects remembered more discrete facts than the exposed, both in the morning ( 7.8 vs. 5.8$)$ and the afternoon (9.3 vs. 7.4$)$, but the differences were not significant. 
Hazara Evaluation and Technical Assistance Report No. 83-369

\section{4. liulti-Attention Task}

flie unexposed subjects icentitied a larcer mean number of distractors ( $29 \& 29)$ curing the test than did the exposer $(2.7 \&$ \& $24)$, and the difference was significaric in the afternoon $(p=0.02)$.

\section{Bourdon-iviersma}

Unexposed subjects inproved from inorning to afternoon (261 vs. 274), but exposed subjects performed better in the morning than in the afternoon ( 226 vs. 222). Group differeuces between exposed and unexposed were higilly significant in the afternonn ( $p=0.001)$ when the unexposec correctly identified 35 more sets than the exposed (261 vs. 226), and in the afternoon when unexposed subjects identified 52 more than those exposed (274 vs. 222) $(p=0.001)$.

\section{DISCUSSION}

Both the Bourdon-Wiersma and the Multi-Attention Task reflect attention and alertness. The significant differences between exposed and nonexposed workers for these two tests, which measure similar or related functions, might suggest there were true differences in attention and alertness between the two groups. However, the group differences in the multi-attention task $(p=.02)$ must be viewed with. some skepticism, because the large numbers of comparisons made in this study can result in occasional spuricus?y statiscically significant associations. Although the Bourdon-wiersma tests, showed a cross-shift improvement in perfurmance for the unexposed group $(+13)$ and a cross-shift, decline $(-4)$ for the exposed group $(p=.04)$, the low solvent vapor concentrations detected duriing the shift when these tests vere given, incicate that test performance difference in the two groups was probabiy a spuriousiy significant association owing to the large numbers of comparisons made. There were no statistically significant differences between groups (either in the morning or across the shift) in any of the other performance tests.

The tests selected for this investigation were sensitive to the effects of exposure for the chemicals stucied, hut the small number of people tested made it unlikely that clear exposure effects would be identified unless the effects were relatively large. To cuunter this, as indicated above, the type of data analysis was essentially exploratory, treating each test as an independent case, which increased the chances of finting statistically significant effects.

Group differences have been seen in four other worksite studies which utilized the Bourdon-biersma. Viscose rayon workers exposed to carhon disulfide, $24,25,26$ polyester plastics workers exposed to styreae, 27 and jet engine workers exposed to jet fue $1^{28}$ a1? 
showed poorer performance on this test, as compared to unexposed comparison subjects. A reduced ability to maintain attention or alertness in the types of tests used here would suggest concern for the safety of persons so-exposed and working with potentially dangerous machinery, or when driving home.

Both the acute symptoms described anecdotally by some workers during past exposures to solvents and the results of the performance testing suggest that there may be a causal relationship. The association is consistent with other studies demonstrating both acute and chronic central nervous system sequelae to solvent exposure. The principle solvents used in Building 84 have been shown to produce acute performance decrements in subjects exposed to levels near the TLV. Decrements in reaction time, perceptual speed and manual dexterity 29 and in balance (positive Romberg test) have been seen in persons exposed to 1,1,1-trichloroethane. 30 Exposure to perchloroethylene at : $100 \mathrm{ppm}$ has been shown to produce performance decrement in coordination. 31 Exposures to enough methylene chloride to produce carboxyhemoglobin levels approaching the recommended biological action level $(5 \%)$ have been shown to produce acute decreases in the speed and precision of psychomotor performance. 32 Chronic methylene chloride exposure has been reported to affect neurologic function in animals 15 , and high exposures have been reported anecdotally to cause chronic toxic brain damage in humans. 33

Cross-sectional studies suggest that chronic exposure to solvents may have serious effects on neuroperformance. 34 Other studies suggest a strong association between solvent-exposure and disease. A case control study of Scandanavian patients with neuropsychiatric disease suggested that previous solvent exposure may account for up to $3 \%$ to $4 \%$ of all such disease.35,36 It was estimated that among solvent exposed patients, nearly $1 / 2$ of all such disease was caused by a previous solvent exposure history. 35

There is some evidence that a synergistic effect occurs from exposures to certain organic vapor mixtures, meaning that a solvent mixture may be more neurotoxic than its individual components, resulting in impaired performance even where exposures are well below the TLV.36,37 Based on this and other evidence, clinical neuro-psychiatric disorders resulting from solvent exposure is now accepted as an occupational disease by the Swedish National Social Insurance Board.38

The results of this NIOSH study should be interpreted with some caution. If the neuroperformance decrements measured were the result of solvent exposures, it is puzzling that higher airborne concentrations were not detected in Building 84 . It is possible that the exposures measured during the day of the NIOSH visit reflected lower exposures than are typically found in Building 84 , or lower than may have existed in the past. It is also possible 
Hazara Evaluation and Technical Assistance Report No. 83-369

that there were other differences in the groups completely unrelated to the exposures that the study team was unaware of. Fur example, the workers from the control group have jobs that require them to be attentive or alert when reading uritten material, which is not the case for the workers in Building 84 . The practice with such tasks could favor the control subjects on tests of attention or alertness. There is a mean difference in the ages of 3.9 years between the exposed and unexposed group. The younger control workers might he expected to perform better than the slightly older exposed workers. Lastly, selection bias may have been introduced by the poor participation rate among a subsegment of the control workers, or workers from shipping and receiving who do well on this type of test may have been the only workers who chose to participate.

VIII. CONCLUSIONS

Although the exposure to volatile organic vapors measured during this investigation were below the limits recommended by NIOSH (except for potential carcinogens), workers from Building 84 scored lower on neurobehavioral performance tests measuring attention and alertness than did the unexposed controls. Although these differences suggest the possibility of effects resulting from long-term low-level solvent exposures prior to the NIOSH on-site investigation, an inadvertent study bias as explained above could also account for these differences.

IX. RECOMMENDATIONS

The NIOSH investigators made the following recommendations after the initial site visit to Building 84 in an interim report submitted to the employee representative and Lockheed-Georqia managenent representatives on September 16,1983 . To the extent feasible, Lockheed complied with these recommendations prior to the NIOSH follow-up survey.

1. The top of the waste solvent storage pit shoulc be covered as much as possitle to prevent solvent vapors from evaporating when the spray booth is not in use.

2. Parts, especially the larger parts, awaiting inspection should be given enough time to dry in the spray booth or placed in an open area where no workers would be exposed.

3. Facial hair should not be allowed for workers assigned to spray clean parts inside the spray booth. Facial hair (even a few days growtli) prevents a good sea 1 between the surface of a respirator facepiece and the wearer's skin.

4. Luckheed should study the feasitility of moving workers not directly involved in spraying to an adjacent building where parcs could be delivered after drying. Otherwise, the inspector's and structural assembiy worker's work henches in Building 84 should be moved as far away from the spray bnoth as possible. 
Hazard Evaluation and Technical Assistance Report No. 83-369

In follow-up to our previous recommendations (No. 3), a recently published study on the effect of facial hair on the face seal of negative-pressure respirators, 39 found that bearded subjects wearing half-mask respirators had a median fit factor of 12 ( $8 \%$ leakage) vs. a fit factor of 2950 ( $0.03 \%$ leakage) for clean shaven subjects. The average quantitative fit test results showed a 240 fold drop in half-mask respirator protection for bearded subjects when compared to the clean shaven subjects.

After reviewing our final results for this investigation NIOSH al so recommends that:

1. Lockheed minimize the use of $T$ urco ${ }^{\circledR} T-1000$ for the spray cleaning of wing parts because this solvent contains two suspected or potential carcinogens (methylene chloride and tetrachloroethylene) in its formulation.

2. Lockheed should evaluate its use of neoprene rubber rain suits for protecting workers from solvent spray. NIOSH recommends buty 1 rubber or Viton ${ }^{\circledR}$ elastomer gloves, aprons, or other protective garments for protection against exposure to liquid phase 1,1,1-trichloroethane. 40 Neoprene rubber latex or nitrile rubber latex may be used in cases where the protective garment will not be in contact with either the liquid or saturated vapor of 1,1,1-trichloroethane.

$X$. AUTHORSHIP AND ACKNOWLEDGEMENTS

Evaluation Conducted and Report Prepared By:

Stan Salisbury, CIH

Regional Industrial Hygienist NIOSH Region IV

Atlanta, Georgia

Rob McConne11, M.D.

Medical officer

Hazard Evaluations and

Technical Assistance Branch

NIOSH, Cincinnati, Ohio

Kent Anger, PhD

Applied Psychology and

Ergonomics Branch

Division of Behavioral and

Biomedical Science

NIOSH, Cincinnati, Ohio

Field Assistance:

Tar-Ching Aw, M.D.

Medical officer

Hazard Evaluations and

Technical Assistance Branch

NIOSH, Cincinnati, Ohio 


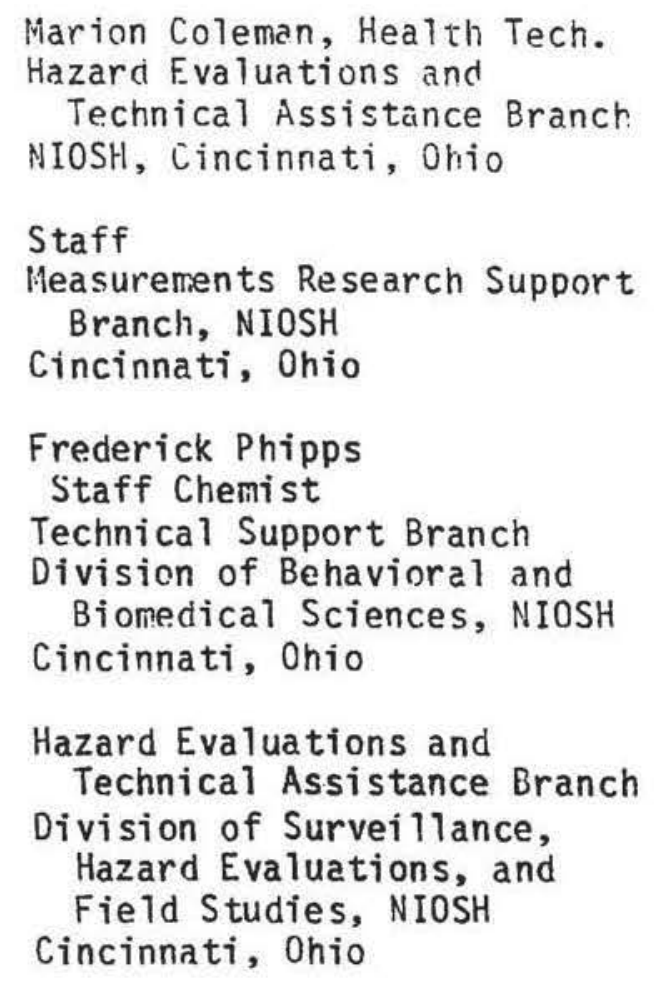

XI. DISTRIBUTION AND AVAILABILITY

Copies of this report are currently available upon request from NIOSH, Division of Standards Development and Technology Transfer, Puilications Dissemination Section, 4676 Columbia Parkway, incinnati, Ohio 45226. After ninety (90) days the report 4111 be available through the National Technical Information Service (NTIS), Springfield, Virainia 22161. Information regarding its availability through NTIS can be obtained from the NIOSH

Publications Office at the Cincinnati, Ghio address.

Copies of this report have been sent to:

1. Lockheed-Georgia. Company

2. Representatives for Employees

3. NIOSH Region IV

4. OSHA Region IV

5. Designated State Agencies of Georgia

For the purpose of inforning the approximateiy 25 "affected employees", the employer will promptly "post" this report for a period of thirty (30) calendar days in a prominent place(s) near where the affected employees work. 
Hazard Evaluation and Technical Assistance Report No. 83-369

\section{REFERENCES}

1. National Institute for Occupational Safety and Health. NIOSH Manual of Analytical Methods. Vol 3, 2nd ed. Cincinnati, $\mathrm{OH}$ : National Institute for Occupational Safety and Health, 1977. (DHEW (NIOSH) Publication No. 77-157-C).

2. National Institute for Occupational Safety and Health. NIOSH Manual of Analytical Methods. Vol 1, 2nd ed. Cincinnati, $\mathrm{OH}$ : National Institute for Occupational Safety and Health, 1977. (DHEW (NIOSH) Publication No. 77-157-A).

3. National Institute for Occupational Safety and Health. NIOSH Manual of Analytical Methods. Vol 1, 2nd ed. Cincinnati, $\mathrm{OH}$ : National Institute for Occupational Safety and Health, 1977. (DHEW (NIOSH) Publication No. 77-157-A).

4. National Institute for Occupational Safety and Health. NIOSH Manual of Analytical Methods. Vol 3, 2nd ed. Cincinnati, $\mathrm{OH}$ : National Institute for Occupational Safety and Health, 1977. (DHEW (NIOSH) Publication No. 77-157-C).

5. Hogstedt, C., Andersson, K., Hane, M., "A Questionnaire Approach to the Monitoring of Early Disturbances in Central Nervous Functions." In Aitio, A., Rhimaki, V., and Vainio, H. (editors). The Biological Monitoring of Exposure to Industrial Chemicals. Hemisphere Publishing Corp., Washington, 1984.

6. Tanaka, S. and Ikeda, "A Method for Determination of Trichloroethanol and Trichloroacetic Acid in Urine." British Jour. of Ind. Med., 25: 214, 1968.

7. NIOSH. Manual of Analytical Methods, 3rd. NIOSH Publication No. 84-100, Feb., 1984.

8. Lauwerys, R., "Industrial Chemical Exposure: Guidelines for Biological Monitoring." Biomedical Publications, Davis, California, 1983.

9. Statistical Analysis System (SAS) Institute. Library User's Guide. SAS Institute, Inc., Cary, North Carolina, 1969.

10. American Conference of Governmental Industrial Hygienists (ACGIH). Threshold Limit Values for Chemical Substances and Physical Agents in the Workroom Environment with Intended Changes for 1985-86. Cincinnati, Ohio: ACGIH, 1985.

11. U.S. Dept. of Labor, Occupational Safety and Health Administration (OSHA). CFR Title 29, Part 1910--Occupational Safety and Health Standards, Subpart Z--Toxic and Hazardous Substances. 
Hazard Evaluation and Technical Assistance Report No. 83-369

12. American Conference of Governmental Industrial Hygienists. Documentation of the threshold limit values. 4th. ed., with supplemental documentation for 1984. Cincinnati, Ohio: ACGIH, 1980.

13. Stewart, R.D., et a1., "Human Exposure to 1,1,1-Trichloroethane Vapor: Relationship of Expired Air and Blood Concentrations to Exposure and Toxicity." Journal of the Industrial Hygiene Association, 22: 252-62, 1961.

14. National Institute for Occupational Safety and Health. Criteria for a Recommended Standard: Occupational Exposure to Methylene Chloride. Cincinnati, Ohio: National Institute for Occupational Safety and Health, 1976. DHEW Publication No. (NIOSH) 76-138.

15. Clayton, G.D. and $\mathrm{Cl}$ ayton, F.E. Patty's Industrial Hygiene and Toxicology. Vol 2B--toxicology, 3rd revised ed. New York: John Wiley \& Sons, 1981.

16. NTP Technical Report of the Toxicity and Carcinogenisis of Dichloromethane (CAS 75-09-2) in F344IN Rats and B6C3F Mice (inhalation studies). NTP 85-024, NIH Publication 85-2562, NTPTR 306, Feb. 85.

17. National Institute for Occupational Safety and Health. NIOSH/OSHA Occupational Health Guidelines for Chemical Hazards. Cincinnati, $\mathrm{OH}$ : National Institute for Occupational Safety and Health, 1981. DHHS (NIOSH) Publication No. 81-123.

18. National Institute for Occupational Safety and Health. The "Dormant Standards": Review of Selected Workplace Hazards. Cincinnati, OH: NIOSH, DSDTT, October, 1984.

19. Environmental Health Letter. Gershon W. Fishbein, Ed. \& Pub. Vol. 25, No. 1, Jan. 1, 1986.

20. National Institute for Occupational Safety and Health. Current Intelligence Bulletin 20, Tetrachloroethylene (perchloroethylene). Cincinnati, Ohio: National Institute for Occupational Safety and Health, 1978. DHEW Publication No. (NIOSH) 78-112.

21. Proctor N.H., Hughes J.P. "Chemical Hazards of the Workplace." Philadelphia: J.B. Lippincott Company, 1978.

22. National Institute for Occupational Safety and Health. Occupational Diseases: a Guide to Their Recognition. Revised ed. Cincinnati, $\mathrm{OH}$ : National Institute for Occupational Safety and Health, 1977. DHEW (NIOSH) Publication No. 77-181. 
Hazard Evaluation and Technical Assistance Report No. 83-369

23. National Institute for Occupational Safety and Health. Criteria for a Recommended Standard: Occupational Exposure to Dioxane. Cincinnati, Ohio: National Institute for Occupational Safety and Health, 1977. DHEW Publication No. (NIOSH) 77-226.

24. Hanninen, H., "Pshchological Picture of Manifest and Latent Carbon Disulfide Poisoning." Br. J. Ind. Med., 28:374, 1971.

25 Hanninen, H., "Behavioral Study of the Effects of Carbon Disulfide." In: Behavioral Toxicology; Early Detection of Occupational Nazards (C. Xinatras, B.L. Johnson, and I. deGroot, eds.). DHEW Publication No. (NIOSH) 74-126, p73, 1974.

26. Tolonen, M. and Hanninen, H., "Psychological Tests Specific to Individual Carbon Disulfide Exposure." Scand. J. Psychol., $19: 241,1978$.

27. Lindstrom, K. et al., Disturbances in Psychological Functions of Workers Occupationally Exposed to Styrene. Scand. J. Work. Environ. Health, 3:129, 1976.

28. Knave. B., et al., "Long Term Exposure to Jet Fuel: A Cross-sectional Epidemiologic Investigation on Occupationally Exposed Industrial Workers with Special Reference to the Nervous System." Scand. J. Work. Environ. Heal th, 4:19, 1978.

29. Gamberale, F., Hultengren, M., "Methylchloroform Exposure II, Psychophysiological Functions." Work. Environm. H1 th., 10: 82-92, 1973.

30. Stewart, R.D., et al., "Experimental Human Exposure to Methyl Chloroform Vapor." Arch. Environ. Health, 19: 467-472, 1969.

31. Hake, C.L., and Stewart, R.D., "Human Exposure to Tetrachloroethylene: Inhalation and Skin Contact." Environm. H1 th. Perspect., 21: 231-238, 1977.

32. Putz, V.R., Johnson, B., Setzer, J., "A Comparative Study of the Effects of Carbon Monoxide and methylene Chloride on Human Performance." Jour. Environm. Pathol. and Toxicol., 2: 97-112, 1978.

33. Barrowcliff, D.F., and Knel1, A.J., "Cerebral Damage Due to Endogenous Chronic Carbon Monoxide Poisoning Caused by Exposure to Methylene Chloride." J. Soc. Occup. Nied., 29: $12-14,1979$.

34. Axelson, 0., et al., "Current Aspects of Solvent-related Disorders," Developments in Occupational Medicine, Year Book Medical Publishers, Chicago, 1980. 
35. Axelson, 0., et al., "A Case-referent Study on Neuropsychiatric Disorders Among Workers Exposed to Solvents." Scand. J. Work. Environ. \& Health, 2: 14-20, 1976.

36. Lindstrom, K., "Behavoral Changes After Long-term Expsoure to Organic Solvents and Their Mixtures." Scand. J. Work. Environ. Health, 7:Suppl. 4, 48-53, 1981.

37. Hanninen, H., et al., "Behavioral Effects of Long-term Exposure to a Mixture of Organic Solvents." Scandanavian J. Work. Environ. Health, 4: 240-255, 1976.

38. Flodin, U., Edline, C., and Axelson, 0., "Clinical Studies of Psychoorganic Syndromes Among Workers with Exposure to Solvents." Am. J. Indust. Med., 5: 287-295, 1984.

39. Skretvedt, O.T. and Loschiavo, J.G., "Effect of Facial Hair on the Face Seal of Negative-pressure Respirators." Am. Ind. Hyg. Assoc. J., 45(1): 63-66, 1984.

40. Weeks, R.W. and McLeod, M.J., "Permeation of Protective Garment Material by Liquid Halogenated Ethanes and a Polychlorinated Biphenyl." DHHS (NIOSH) Publication No. 81-110, January, 1981.

41. National Institute for Occupational Safety and Health. Criteria for a Recommended Standard: Occupational Exposure to 1,1,1-trichloroethane. Cincinnati, Ohio: National Institute for Occupational Safety and Health, 1976. DHEW Publication No. (NIOSH) 76-184.

42. National Institute for Occupational Safety and Health. Criteria for a Recommended Standard: Occupational Exposure to Xylene. Cincinnati, Ohio: National Institute for Occupational Safety and Health, 1975. DHEW Publication No. (NIOSH) 75-168. 
TABLE 1

DEMOGRAPHIC \& OTHER CHARACTERISTICS

OF SOLVENT EXPOSED WORKERS AND CONTROLS

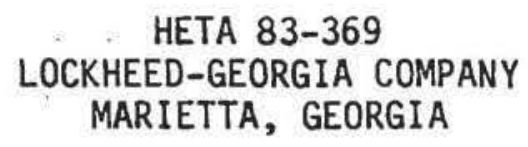

(February 1984)

\begin{tabular}{|c|c|c|}
\hline & $\begin{array}{c}\begin{array}{c}\text { Exposed }(N=7) \\
\text { Number }(\%)\end{array} \\
\end{array}$ & $\begin{array}{l}\text { Not Exposed }(\mathrm{N}=13) \\
\text { Number }(\%)\end{array}$ \\
\hline Caucasian & $4(71)$ & $9(69)$ \\
\hline Black & $3(43)$ & $3(23)$ \\
\hline Male & $6(86)$ & $11(85)$ \\
\hline Female & $1(14)$ & $2(15)$ \\
\hline Prior job with chemical exposure & $5(71)$ & $12(92)$ \\
\hline Drinkers (>6 drinks/week) & $2(29)$ & $4(31)$ \\
\hline Drinkers ( $>1$ drink in last 24 hrs.) & $2(22)$ & $1(8)$ \\
\hline Medications affecting nervous system & $1(14)$ & $4(31)$ \\
\hline Smokers & $1(14)$ & $6(46)$ \\
\hline Age (mean in years) & 46.9 & 43.3 \\
\hline
\end{tabular}


for SUBSTANCES MEASURED in BUILDING 840

HETA $83-369$

LOCKHEED-GEORGIA COMPANY

MARIETTA, GEORGIA

(February 1984)

\begin{tabular}{|c|c|c|c|c|c|}
\hline SUBSTANCE & OSHA PEL** & ACGIH TLV*** & $\begin{array}{l}\text { NIOSH } \\
\text { RECOMMENDATION }\end{array}$ & $\begin{array}{l}\text { HEALTH EFFECTS } \\
\text { CONSIDERED }\end{array}$ & REFERENCE \\
\hline $\begin{array}{l}\text { 1'1'1-trichl oroethane } \\
\text { (methyl chloroform) }\end{array}$ & $350 \mathrm{ppm}$ & $350 \mathrm{ppm}$ & $\begin{array}{c}350 \mathrm{ppm} \\
\text { (ceiling-15 min) }\end{array}$ & $\begin{array}{l}\text { Nervous system, liver, \& } \\
\text { heart effects }\end{array}$ & 41 \\
\hline Perchl oroethylene & 100 ppm & $50 \mathrm{ppm}$ & LTFL & $\begin{array}{l}\text { Nervous system effects; } \\
\text { respiratory, eye, \& skin } \\
\text { irritation; suspect carcinoger }\end{array}$ & 20 \\
\hline Trimethyl benzene & -- & $25 \mathrm{ppm}$ & -- & $\begin{array}{l}\text { Mucous membrane irritation, } \\
\text { nervous system effects }\end{array}$ & 12 \\
\hline Methylene chloride & $500 \mathrm{ppm}$ & $100 \mathrm{ppm}$ & $75 \mathrm{ppm}$ & $\begin{array}{l}\text { Central nervous system } \\
\text { effects, carbon monoxide } \\
\text { toxicity }\end{array}$ & 14 \\
\hline Xylene & 100 ppm & $100 \mathrm{ppm}$ & 100 ppm & $\begin{array}{l}\text { Central nervous system } \\
\text { depressant, respiratory } \\
\text { irritation }\end{array}$ & 42 \\
\hline n-Butyl alcohol & 100 ppm & $\begin{array}{c}50 \text { ppm } \\
\text { (ceiling-15 min) }\end{array}$ & -- & $\begin{array}{l}\text { Eye \& mucous membrane } \\
\text { irritation, hearing loss \& } \\
\text { impaired vestibular function }\end{array}$ & 12 \\
\hline Diacetone alcohol & $50 \mathrm{ppm}$ & $50 \mathrm{ppm}$ & -- & $\begin{array}{l}\text { Eye, nose, \& throat } \\
\text { irritation; objectionable } \\
\text { odor \& taste }\end{array}$ & 12 \\
\hline
\end{tabular}

* Limits are 8-hour time-weighted averages (TWA) unless otherwise stated.

** For OSHA standards, see Reference No. 10

$\star \star \star$ For ACGIH TLV's, see Reference No. 11

$\mathrm{ppm}=$ parts per million parts of air

LTFL = lowest technically feasible limit 
TABLE 3

RESULTS OF AIR MONITORING FOR SOLVENT VAPORS

\author{
HETA 83-369 \\ LOCKHEED-GEORGIA COMPANY \\ MARIETTA, GEORGIA
}

(February 1984)

Job Classification/

Sampling Location

Building 84:

Solvent sprayer

Inspector

Structural repairman

Inspector

Insp. bench (area)

Core cutter mechanic

\section{Sampling Duration}

February 7, 1984: $8: 20 \mathrm{am}-12: 37 \mathrm{pm}$ $8: 10 \mathrm{am}-1: 38 \mathrm{pm}$ $8: 25 \mathrm{am}-1: 30 \mathrm{pm}$ $9: 51 \mathrm{am}-12: 16 \mathrm{pm}$ $8: 50 \mathrm{am}-1: 00 \mathrm{pm}$ $10: 08 \mathrm{am}-1: 20 \mathrm{pm}$

\begin{tabular}{|c|c|c|c|c|c|}
\hline PERC & TMB & MC & Xylene & Butanol & $\mathrm{DA}$ \\
\hline 2.8 & 1.1 & 5.8 & 0.2 & 0.2 & 0.2 \\
\hline 0.2 & ND & 0.5 & ND & NS & NS \\
\hline 0.3 & 0.1 & ND & ND & NS & NS \\
\hline 0.5 & 0.1 & NS & ND & 0.5 & ND \\
\hline 0.4 & 0.2 & ND & ND & ND & ND \\
\hline 0.6 & ND & 2.2 & ND & NS & NS \\
\hline
\end{tabular}

Control Subjects: Receiving inspector Traffic office worker Receiving inspector Tool design tech Tool designer Tool designer

\begin{tabular}{llll} 
& \multicolumn{2}{r}{ Solvent } \\
\cline { 2 - 2 } February $6 \& 8,1984:$ & PERC & & TMB \\
$1: 53 \mathrm{am}-2: 16 \mathrm{pm}$ & & & \\
$10: 20 \mathrm{am}-2: 24 \mathrm{pm}$ & ND & & ND \\
$10: 06 \mathrm{am}-2: 18 \mathrm{pm}$ & ND & & ND \\
$10: 36 \mathrm{am}-2: 40 \mathrm{pm}$ & ND & & ND \\
$8: 16 \mathrm{am}-12: 30 \mathrm{pm}$ & ND & & ND \\
$8: 57 \mathrm{am}-12: 32 \mathrm{pm}$ & ND & & ND \\
$10: 24 \mathrm{am}-1: 12 \mathrm{pm}$ & ND & & ND \\
& ND & ND
\end{tabular}

Solvent Vapor Levels for Controls

Paint stores rec. Insp. 10:24am-1:12pm

All samples represent personal exposures unless otherwise noted

All exposures in parts per million ( $\mathrm{ppm}$ )

Recommended occupational exposure limits (TWA) 50

PERC = perchloroethylene

TMB = trimethyl benzene (aromatic petrolium solvent)

$M C=$ methylene chloride

$D A=$ diacetone alcohol

ND = none detected

NS $=$ not sampled

TWA $=8$-hour time weighted average

${ }^{\star} \mathrm{C}=$ ceiling limit

LTFL = Lowest Technically Feasible Limit (NIOSH recommended limit for known or suspected carcinogens) 
TABLE 4

RESULTS OF AIR MONITORING FOR 1,1,1-TRICHLOROETHANE VAPORS

\author{
HETA 83-369 \\ LOCKHEED-GEORGIA COMPANY \\ MARIETTA, GEORGIA \\ (February 1984)
}

Job Classification/ Sampling Location
Sampling Duration Exposures During Use of Solvent 111

$$
\begin{array}{r}
12: 14 \mathrm{pm}-3: 03 \mathrm{pm} \\
12: 40 \mathrm{pm}-3: 02 \mathrm{pm} \\
12: 30 \mathrm{pm}-2: 58 \mathrm{pm} \\
12: 37 \mathrm{pm}-2: 56 \mathrm{pm} \\
1: 07 \mathrm{pm}-2: 56 \mathrm{pm} \\
1: 30 \mathrm{pm}-3: 00 \mathrm{pm} \\
1: 38 \mathrm{pm}-3: 01 \mathrm{pm} \\
1: 21 \mathrm{pm}-2: 44 \mathrm{pm}
\end{array}
$$

$0.7 \mathrm{ppm}$

$1.0 \mathrm{ppm}$

$1.1 \mathrm{ppm}$

$23.0 \mathrm{ppm}$

$1.0 \mathrm{ppm}$

$0.6 \mathrm{ppm}$

$0.5 \mathrm{ppm}$

$1.6 \mathrm{ppm}$

Al1 samples represent personal exposures unless otherwise noted 
TABLE 5

SYMPTOM AND DISEASE PREVALENCE

SOLVENT EXPOSED WORKERS \& CONTROLS

HETA 83-369

LOCKHEED-GEORGIA COMPANY

MARIETTA, GEORGIA

(February 1984)

Symptom or Disease

Exposed (\%) Not Exposed (\%) p value

"Have you ever been seen by a doctor for:"

Diabetes
Migraine
Heart Disease (including arrhythmias)
Liver Disease
Kidney Disease
High Blood Pressure
Neurologic Disease
Asthma
Upper Respiratory Disease

0

$1(14.3)$

$2(15.4)$

0

0

$4(57.1)$

0

$2(28.6)$

$2(28.6)$
$1(7.7)$

.87

$0 \quad .72$

$0 \quad .68$

$2(15.4) \quad .68$

$1(7.7) \quad .81$

$6(46.2) \quad .93$

0

$1(7.7)$

$5(38.5)$
1.00

.58

.79

"In general, are you troubled by the following:"

Fatigue

Vegetative Symptoms

Parathesias

Affect Lability

Lack of Concentration

Memory Difficulty

Gross Neuropathic Symptoms

Lack of Sexual Interest

S1 eepiness

Excited for no Reason

Unusual Taste
$1(14.3)$

$2(28.6)$

$2(18.6)$

$1(14.3)$

$2(28.6)$

$1(14.3)$

0

0

$2(28.6)$

0

$1(14.3)$
0

$4(30.8)$

$1(7.7)$

$8(61.5)$

$1(7.7)$

$8(61.5)$

0

$2(15.4)$

$6(46.2)$

0

$1(7.7)$
.75

1.00

.60

.74

.60

.21

1.00

.74

.78

1.00

.87

"During the past two weeks have you had:"

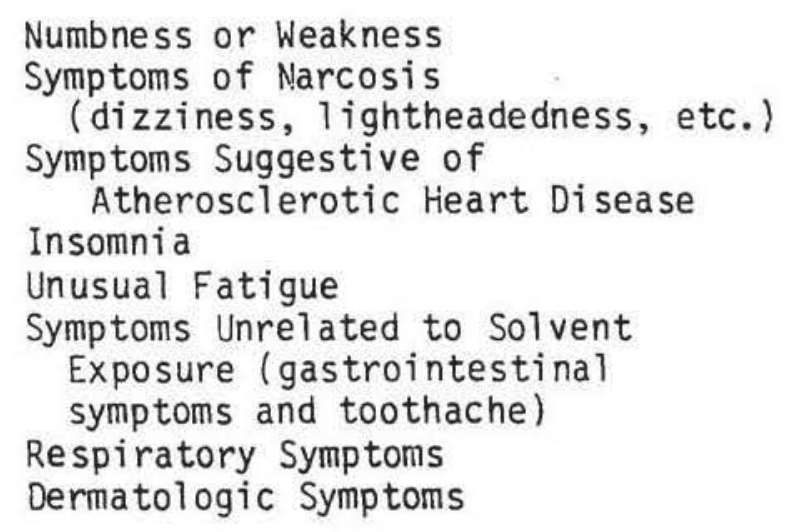

Dermatologic Symptoms

$2(15.4)$

$1(7.7)$

$2(15.4)$

$2(15.4)$

$1(14.3)$

$1(14.3)$

0

$3(42.9)$

$3(42.9)$
$6(46.2)$

$3(23.1)$
.59

.58

.86

.97

.75

1.00 


\title{
TABLE 6
}

BEHAVIORAL TEST RESULTS

SOLVENT EXPOSED WORKERS VS. UNEXPOSED WORKERS

\author{
HETA 83-369 \\ LOCKHEED-GEORGIA COMPANY \\ MARIETTA, GEORGIA
}

(February 1984)

Simple Reaction Time (release)

Preshift

Postshift

difference (postshift-preshift)

Simple reaction time (response)

\section{Preshift}

Postshift

Difference (postshift-preshift)

Santa Ana Test

Preshift

Postshift

Difference (postshift-preshift)

Wechsler Memory Scale

\section{Preshift}

Postshift

Difference (postshift-preshift)

Multi-Attention Task

Preshift

Postshift

Difference (postshift-preshift)

Bourdon-Wiersma

Preshift

Postshift

Difference (postshift-preshift)

\begin{tabular}{|c|c|c|}
\hline \multicolumn{3}{|c|}{ AVERAGE SCORES } \\
\hline UNEXPOSED & EXPOSED & PROBABILITY \\
\hline $\begin{array}{l}329 \mathrm{msec} \\
376 \mathrm{msec} \\
+47\end{array}$ & $\begin{array}{c}338 \mathrm{mse} \\
329 \mathrm{mse} \\
-9\end{array}$ & $\begin{array}{l}0.61 \\
0.40 \\
0.40\end{array}$ \\
\hline
\end{tabular}

$\begin{array}{rrr}185 \mathrm{msec} & 206 \mathrm{msec} & 0.28 \\ 193 \mathrm{msec} & 212 \mathrm{msec} & 0.13 \\ +8 & +6 & 0.53\end{array}$

17 pegs

18 pegs

$\overline{19}$ pegs

$0 .-$

$+1$

--

--

$\begin{array}{rrr}7.8 \text { facts } & 5.8 \text { facts } & 0.24 \\ 9.3 \text { facts } & 7.4 \text { facts } & 0.10 \\ +1.5 & +1.6 & 0.50\end{array}$

29 dist.

29 dist.

27 dist

0.19

24 dist.

$-3$

0.02

0.07

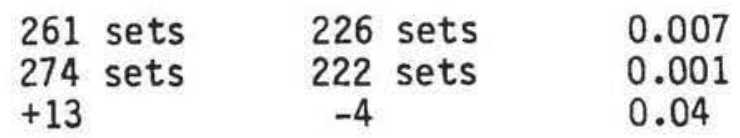


RTMENT OF HEALTH AND HUMAN SEAVICES

PUELIC MEALTM gERVICE

EENTEKS TOR DISEAGE CONTHOL

VAL INSTITUTE FOR OCCUPATIONAL SAFETY AND WEALTH

ROBEAT A. TAFT LABOAATOAIES

4878 COLUMEIA PARKWAY, CINGINNATI, OHIO 45220

OFFICIAL BUSINESS

PENALTY FOA PAIVATE USE $\$ 000$
Third Class Mail

MOSTAGE AND FEEE PAID

US. DEPANTMENT OF HWS HKS 300 